\title{
Molecular characterization of the NSP4 gene of human group A rotavirus samples from the West Central region of Brazil
}

\author{
Talissa de Moraes Tavares, Wilia Marta Elsner Diederichsen de Brito, Fabíola Souza Fiaccadori, \\ Erika Regina Leal de Freitas, Juliana Alves Parente', Paulo Sérgio Sucasas da Costa², \\ Loreny Gimenes Giugliano ${ }^{3}$, Márcia Sueli Assis Andreasi ${ }^{4}$, Célia Maria Almeida Soares ${ }^{1}$, \\ Divina das Dôres de Paula Cardoso/ ${ }^{+}$
}

\begin{abstract}
Laboratório de Virologia, Instituto de Patologia Tropical e Saúde Pública ${ }^{1}$ Laboratório de Biologia Molecular, Instituto de Ciências

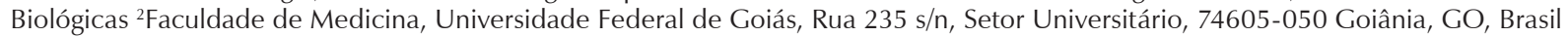
${ }^{3}$ Departamento de Biologia Celular, Universidade de Brasília, Brasília, DF, Brasil ${ }^{4}$ Departamento de Patologia, Universidade Federal de Mato Grosso do Sul, Campo Grande, MS, Brasil
\end{abstract}

Nonstructural protein 4 (NSP4), encoded by group A rotavirus genome segment 10, is a multifunctional protein and the first recognized virus-encoded enterotoxin. The NSP4 gene has been sequenced, and five distinct genetic groups have been described: genotypes A-E. NSP4 genotypes A, B, and C have been detected in humans. In this study, the NSP4-encoding gene of human rotavirus strains of different $G$ and $P$ genotypes collected from children between 1987 and 2003 in three cities of West Central region of Brazil was characterized. NSP4 gene of 153 rotavirus-positive fecal samples was amplified by reverse transcriptase-polymerase chain reaction and then sequenced. For phylogenetic analysis, NSP4 nucleotide sequences of these samples were compared to nucleotide sequences of reference strains available in GenBank. Two distinct NSP4 genotypes could be identified: 141 (92.2\%) sequences clustered with NSP4 genotype B, and 12 sequences (7.8\%) clustered with NSP4 genotype A. These results reinforce that further investigations are needed to assess the validity of NSP4 as a suitable target for epidemiologic surveillance of rotavirus infections and vaccine development.

Key words: group A rotavirus - NSP4 gene - genotypes - West Central region - Brazil

Group A rotaviruses are a major cause of gastroenteritis in infants and young children throughout the world. Each year, these viruses cause approximately 111 million episodes of severe diarrhea, which results in 611,000 deaths (Parashar et al. 2006). In Brazil, the frequency of group A rotavirus infection among young children was found to be between 12 and $42 \%$ (Linhares 2000, Cardoso et al. 2003, Costa et al. 2004, Cauás et al. 2006, Munford et al. 2007), and about 80,000 children are hospitalized for the infection yearly (Linhares 2000). Viral particles consist of a non-enveloped, triplelayer protein capsid structure that surrounds a genome composed of 11 segments of double-stranded RNA. The genome encodes six structural proteins (VP1-VP4, VP6 and VP7) and six nonstructural proteins (NSP1-NSP6) (Estes \& Kapikian 2007).

Variability in the genes encoding VP7 and VP4 proteins forms the basis of the current strain typing of group A rotaviruses into $\mathrm{G}$ and $\mathrm{P}$ genotypes, respectively. Studies of rotavirus infections in humans have identified distinct $\mathrm{G}$ and $\mathrm{P}$ genotypes circulating simultane-

\footnotetext{
Financial support: $\mathrm{CNPq}$

+ Corresponding author: dcardoso@iptsp.ufg.br

Received 28 January 2008

Accepted 8 May 2008
}

ously in different parts of the world (Santos \& Hoshino 2005, Estes \& Kapikian 2007, Gulati et al. 2007, Martella et al. 2007, Munford et al. 2007, Matthijnssens et al. 2008). There is currently only limited information available on the detection or genetic variability of the gene that encodes nonstructural protein 4 (NSP4) (Ciarlet et al. 2000, Mori et al. 2002, Iturriza-Gómara et al. 2003, Araújo et al. 2007, Mascarenhas et al. 2007).

NSP4, encoded by segment 10, is a transmembrane glycoprotein of 175 amino acids (aa) (Estes \& Kapikian 2007). NSP4 serves as an intracellular receptor for the budding of subviral double-layered particles into the endoplasmic reticulum, a step that is critical for the acquisition of a transient viral membrane and viral particle maturation (Taylor \& Bellamy 2003). In addition, NSP4 has been found to have an enterotoxin-like activity that was originally mapped between aa 114 and 135 . Modifications in the toxigenic activity and virulence of rotavirus have been associated with aa changes in this region (Ball et al. 1996, Zhang et al. 1998). Finally, it has been proposed that antibodies against NSP4 might reduce both the frequency and severity of diarrhea in mice. Together with studies in human infants, these data suggest that the immune response to NSP4 could modulate rotavirus-induced diarrhea in human disease (Ball et al. 1996, Yuan et al. 2004, Vizzi et al. 2005).

The NSP4 genes of animal and human rotavirus have been sequenced and compared. Sequence analyses have revealed the existence of five distinct NSP4 genotypes: A (KUN), B (Wa), C (AU-1), D (EW) and E (avian-like). 
Genotypes A, B, C and D have been determined from mammalian rotavirus strains, while genotype $\mathrm{E}$ has been identified from avian rotavirus strains. Genotypes $\mathrm{A}, \mathrm{B}$ and $\mathrm{C}$ have been detected in humans (Ciarlet et al. 2000, Mori et al. 2002, Lin \& Tian 2003).

In Brazil, there are a few molecular studies of the rotavirus NSP4 gene from strains of diverse origin and various $G$ and $P$ genotypes (Cunliffe et al. 1997, Masca-renhas et al. 2006, 2007, Araújo et al. 2007). As yet, however, there has been no investigation into the detection rate and the genetic diversity of NSP4 genes in the West Central region of Brazil. This study presents novel epidemiological data regarding the circulation of NSP4 genotypes of rotaviruses samples recovered from children in three cities of the West Central region of Brazil.

\section{PATIENTS, MATERIALS AND METHODS}

Samples - The NSP4 gene was investigated in 330 rotavirus A-positive fecal samples that were previously obtained from infected children during surveillance studies performed at the Laboratory of Virology of Universidade Federal de Goiás (UFG) in the city of Goiânia, Brazil. These samples were collected from children up to five years of age with $(\mathrm{n}=325)$ or without $(\mathrm{n}=5)$ acute gastroenteritis between August 1987 and September 2003 in three cities of West Central region, Brazil: Goiânia (GO), Campo Grande (CG) and Brasília (BRA). A total of 202 group A rotavirus samples were identified in GO from 1987 to 2001, 81 samples in CG between 2000 and 2003 and 47 samples in BRA in 2001 and 2002. All samples from GO and CG were collected "in nature", whereas, of the samples collected in BRA, only eight were collected "in nature" and 39 were collected by rectal swab. All of the collected samples had been previously identified as group A rotavirus (Cardoso et al. 2003, Souza et al. 2003, Costa et al. 2004, Andreasi et al. 2007) with a combined enzyme immunoassay for rotavirus and adenovirus (Pereira et al. 1985) and/or by polyacrylamide gel electrophoresis (Pereira et al. 1983).

Specimens were collected from children after signed written consent was provided by their parents or other legal guardians. This study was approved by the Ethics Committee of the Research of UFG (Protocol $\left.\mathrm{n}^{\circ} .004 / 2000\right)$.

RNA extraction - The viral dsRNA was extracted from $20 \%$ fecal suspension by the glass powder method, using guanidine isothiocyanate buffer and silica as described by Boom et al. (1990) with modifications (Cardoso et al. 2002).

Reverse transcription-polymerase chain reaction (RT-PCR) amplification - The RT-PCR followed the protocol described by Lee et al. (2000). The purified viral double-stranded RNA (dsRNA) was denatured at $97^{\circ} \mathrm{C}$ for $10 \mathrm{~min}$ and then used as template for the RT-PCR. The RT of dsRNA was carried out with SuperScript ${ }^{\mathrm{TM}}$ (Invitrogen Carlsbad, CA, USA), and PCR amplification was performed with Taq DNA polymerase (Invitrogen Carlsbad, CA, USA). Fragments of the NSP4 gene of $725 \mathrm{bp}$ were amplified using forward (10BEG16) and reverse (10END722) primers as described by Lee et al. (2000).
Sequencing reaction - The PCR products were purified using the QIAquick ${ }^{\circledR}$ PCR purification kit (Qiagen, São Paulo, Brazil). The PCR-purified products were sequenced by a MegaBACE 1000 automatic sequencer (GE Healthcare, Sunnyvale, USA), using a DYEnamic ET Dye Terminator Cycle Sequencing Kit (GE Healthcare, Buckinghamshire, United Kingdom). The primers used were the same as for PCR amplification. The products were further purified by ethanol precipitation and resuspended in formamide.

Sequence analysis - The sequences obtained were analyzed with PHRED/PHRAP/CONSED (http:// www.phrap.org) and pre-processed using the Phred (Ewing \& Green 1998) and Crossmatch (http://www. genome.washington.edu/UWGC/analysistools/Swat. $\mathrm{cfm})$ programs. Only sequences with at least $100 \mathrm{nu}-$ cleotides and Phred quality greater than or equal to 20 were considered for further analysis with the Blastn program (Altschul et al. 1990) in the National Center for Biotechnology Information Database (http://www.ncbi. nlm.nih.gov). NSP4 sequences were aligned and compared to NSP4 sequences of standard reference strains [AU-1 (D89873), AU32 (D88830), Ch-1 (AB065287), EW (U96335), KUN (D88829), RV5 (U59103), OSU (D88831), Wa (AF093199)] and Brazilian strains [rj5348 (DQ498179) and rj7363 (DQ498192)] available in GenBank using Clustal X software (Thompson et al. 1997). NSP4 genotypes were determined by phylogenetic analysis using the neighbor-joining algorithm method (Saitou \& Nei 1987).

Nucleotide sequence accession numbers - The NSP4 nucleotide sequence data determined in this study were deposited into the GenBank sequence database with accession numbers: EU620072-EU620111.

Statistical analysis - The statistical analysis was performed with the Epi Info version 6 program, using the chi-squared $\left(\chi^{2}\right)$ test for proportion comparison. Statistical significance was assessed at a $p$ value of $<0.05$.

\section{RESULTS}

The NSP4 gene was detected in $259(78.5 \%)$ of 330 rotavirus A-positive fecal samples. Of them, rates of $82.7 \%$ (167/202), 85.2\% (69/81) and 48.9\% (23/47) were observed in fecal specimens from children in $\mathrm{GO}, \mathrm{CG}$ and BRA, respectively $\left(\chi^{2}=28.55, \mathrm{p}=0.000\right)$.

A total of 231 samples that had an amplified NSP4 gene were submitted to sequencing. NSP4 nucleotide sequences of $153(66.2 \%)$ samples could be analyzed and were compared to nucleotide sequences of prototype strains. Of those, 141 sequences $(92.2 \%)$ clustered with NSP4 genotype B with degrees of identity ranging from $89.0 \%$ to $99.0 \%$; and the remaining 12 sequences (7.8\%) clustered with NSP4 genotype A $(93.0 \%-95.0 \%$ of identity). Genotype A samples were identified only in children from GO, while genotype B samples were identified in samples from all three cities (Table I). In GO, the only sample collected in 1987 was genotype B; in the 1990s, however, both genotypes A and B were detected in the 45 samples analyzed, with genotype B (73.3\%) predominating. From 2000 to 2003, only genotype B samples were found to be circulating in the three cities analyzed (Table II). 


\section{TABLE I}

Distribution of nonstructural protein (NSP4) genotypes of group A rotaviruses samples from infected children ${ }^{a}$ from three cities of West Central region of Brazil

\begin{tabular}{lccccc}
\hline & Samples & \multicolumn{2}{c}{ Genotype A } & \multicolumn{2}{c}{ Genotype B } \\
\cline { 2 - 7 } Cities-States & $\mathrm{n}$ & $\mathrm{n}$ & $\%$ & $\mathrm{n}$ & $\%$ \\
\hline Goiânia-GO & 91 & 12 & 13.2 & 79 & 86.8 \\
Campo Grande-MS & 51 & - & - & 51 & 100.0 \\
Brasília-DF & 11 & - & - & 11 & 100.0 \\
Total & 153 & 12 & 7.8 & 141 & 92.2 \\
\hline
\end{tabular}

$a$ : children with $(\mathrm{n}=151)$ and without $(\mathrm{n}=2)$ diarrhea.

\section{TABLE II}

Distribution of NSP4 genotypes of group A rotaviruses samples from infected children ${ }^{a}$ from West Central region of Brazil considering the year of collection

\begin{tabular}{lcccccc}
\hline & Samples & \multicolumn{2}{c}{ Genotype A } & \multicolumn{2}{c}{ Genotype B } \\
\cline { 2 - 6 } Year of collection & $\mathrm{n}$ & $\mathrm{n}$ & $\%$ & $\mathrm{n}$ & $\%$ \\
\hline $1990-1999$ & 45 & 12 & 26.7 & 33 & 73.3 \\
$2000-2003$ & 107 & - & - & 107 & 100.0 \\
Total & $152^{b}$ & 12 & 7.9 & $140^{b}$ & 92.1 \\
\hline
\end{tabular}

$a$ : children with $(\mathrm{n}=150)$ and without $(\mathrm{n}=2)$ diarrhea; $b$ : the only sample identified in 1987 characterized as NSP4 genotype B was not included.

Rotavirus samples P[8]G1, P[6]G1, P[8]G2, P[8]G3, $\mathrm{P}[8] \mathrm{G} 4$ and $\mathrm{P}[8] \mathrm{G} 9$ were more closely related to NSP4 genotype $\mathrm{B}$, whereas $\mathrm{P}[6] \mathrm{G} 9$ rotavirus samples were closely related to NSP4 genotype A. All of these samples that clustered into genotype A or B had human origin (Fig. 1, Table III).

NSP4 genotypes A and B were identified in children with or without acute gastroenteritis. Of the 153 samples, 151 were from children with diarrhea, and two were from children without diarrhea. No significant differences were found in the nucleotide sequences of the NSP4 genes from symptomatic and asymptomatic samples.

The deduced aa sequences of the NSP4 genes of 15 human group A rotavirus samples were aligned with aa sequences of reference prototype strains (Fig. 2). Variations between sequences of genotypes A and B were found in the H3 cytoplasmic domain (aa 63-80), amphipathic alpha-helix domain (aa 93-133), VP4 binding site (aa 112-146), interspecies variable domain (aa 131-141) and VP6 binding site (aa 156-175). Changes were also identified in aa 89, 148, 153 and 154.

Several significant aa differences were observed between distinct NSP4 genotypes, mainly in the interspecies variable domain (Fig. 2, marked in gray box) and in the VP6 binding site (Fig. 2, indicated by diamonds).

In the region proposed to be the enterotoxigenic domain (aa 114-135), the following changes were observed: (Y-H) and (K-N) at aa 131 and 133, respectively (Fig. 2, indicated by asterisks). No differences in the aa sequences of NSP4 were observed between samples from children with or without diarrhea (Fig. 2).

\section{DISCUSSION}

In this study, a detection rate of $78.5 \%$ was observed for the NSP4-encoding gene from rotavirus-positive fecal samples collected in three cities located in the West Central region of Brazil. We speculate that the NSP4 gene could not be detected in all samples due to degradation of the RNA probably as a result of: i) low number of particles present in fecal specimens from rectal swabs; ii) RNA degradation by RNAses; iii) repeated freezing and unfreezing of these samples; iv) preservation of fecal specimens at $-20^{\circ} \mathrm{C}$ and not at $-70^{\circ} \mathrm{C}$; v) defective particle; presence and/or vi) eventual inhibitor persistence of the RT-PCR.

Although five rotavirus NSP4 genotypes have been identified to date (Ciarlet et al. 2000, Mori et al. 2002, Lin \& Tian 2003), most of the diversity in the NSP4-encoding gene among human rotaviruses lies in genotypes $\mathrm{A}$ and B (Iturriza-Gómara et al. 2003). Other studies, however, have detected unusual strains. Cho et al. (2006) observed that two human rotavirus samples in Seoul had a low degree of homology with the currently described NSP4 genotypes, suggesting a possible new NSP4 genotype.

In this study, NSP4 genotypes A and B could be recognized in human group A rotavirus-positive fecal samples. These results are similar to those described by other authors in Brazil (Mascarenhas et al. 2006, 2007, Araújo et al. 2007) and in other countries (Kirkwood et al. 1999, Lee et al. 2000, Iturriza-Gómara et al. 2003, Cho et al. 2006). None of the samples analyzed in our study were closely related to the AU-1 prototype strain, which was isolated from humans and described as NSP4 genotype C (Iturriza-Gómara et al. 2003).

Our data show that genotype B was the most frequently detected (92.2\%) genotype in the West Central region. Similar data were also observed in the Southeast region of Brazil (Araújo et al. 2007) as well as in other countries (Kirkwood et al. 1999, Lee et al. 2000, IturrizaGómara et al. 2003, Cho et al. 2006); however, different results were observed in the Northern region of Brazil, where genotype A was predominant (Mascarenhas et al. 2006, 2007). Genotype A samples were identified only in children from GO, while genotype B samples were identified in all three cities. In GO, genotype A was found only in the 1990s; however, after 2000, it seemed to be replaced by genotype B. Furthermore, the only sample identified in 1980s was genotype B, suggesting that the circulation of NSP4 genotypes changes over time. After 2000, genotype B was also found in CG and BRA. In Rio de Janeiro (RJ), it was shown that genotype B circulated during the years 1986-1988, 1990 and 2001-2004, while genotype A circulated only in 2002 (Araújo et al. 2007). Both genotypes A and B were identified during the 1990s and in 2000 from children in Belém (Mascarenhas et al. 2007).

Worldwide, several studies have compared the NSP4 genes of different rotavirus strains isolated from diarrheic and non-diarrheic children (Cunliffe et al. 1997, Lee et al. 2000, Mascarenhas et al. 2007). In this study, NSP4 genes were identified in children with or without diarrhea, but no differences were observed in the nucleotide 


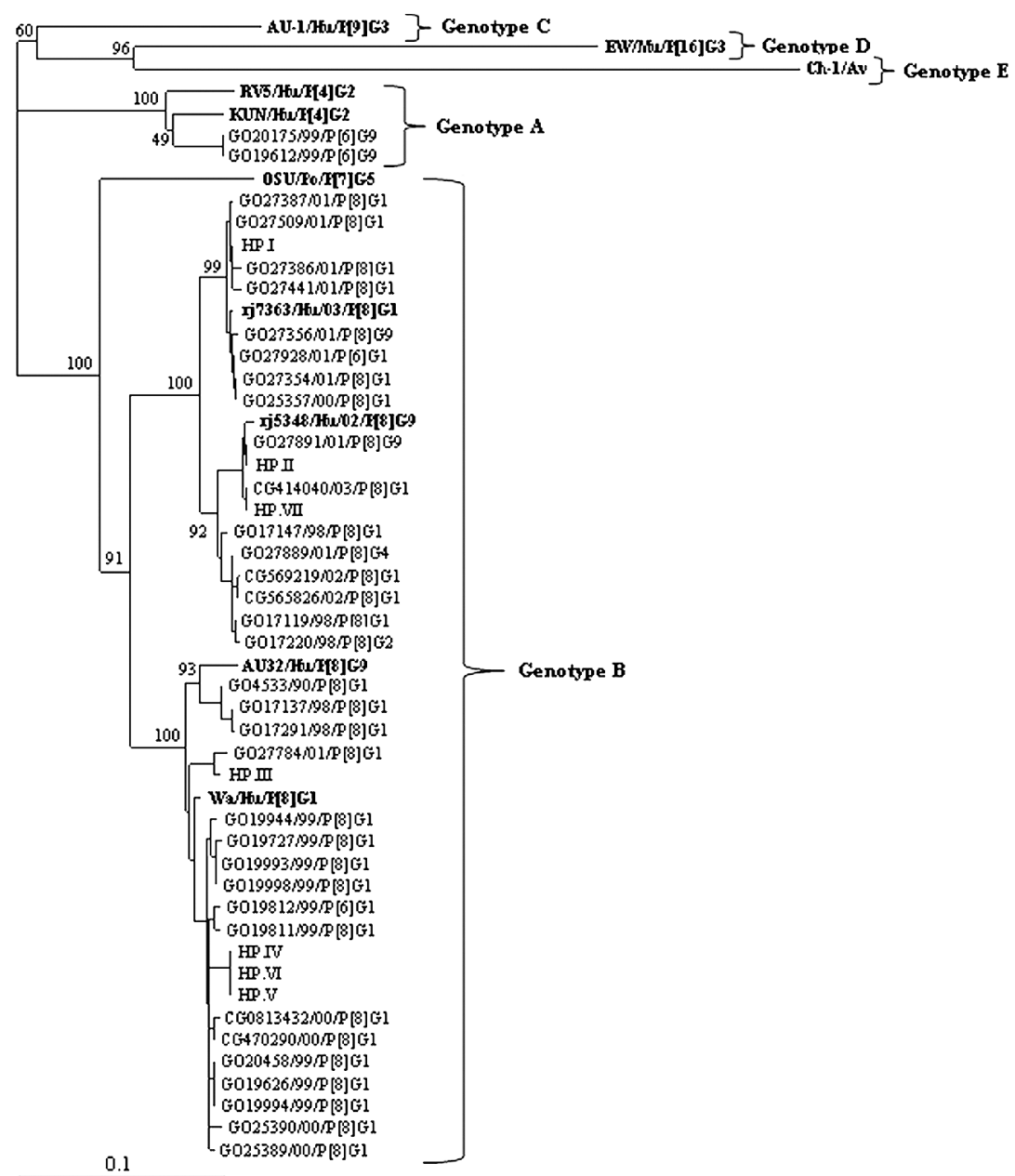

Fig. 1: phylogenetic analysis of nucleotide sequences of group A rotavirus nonstructural protein (NSP4) gene. Nucleotide sequences of prototype strains of NSP4 genotypes A-E obtained from GenBank are represented in bold. Nucleotide sequences of OSU/Po prototype, rj5348/ $\mathrm{Hu}$ and rj7363/Hu strains obtained from GenBank were also included to better understand the phylogenetic relationships among strains. For each sample, the designation in relation to geographical location (BRA: Brasília; CG: Campo Grande; GO: Goiânia), sample number, year of collection, and G and P genotypes are shown. Group samples in which NSP4 nucleotide sequences showed $100 \%$ identity were designated as haplotypes (HP) (I-VII). HP.I: is represented by BRA266/01/P[8]G1, BRA270/01/P[8]G1, GO27440/01/P[8]G1, GO27783/01/P[8]G1 and GO27821/01/P[8]G1 samples; HP.II: is represented by BRA275/01/P[8]G1 and GO27892/01/P[8]G9 samples; HP.III: is represented by CG1676/01/P[8]G4 and CG2670/01/P[8]G4 samples; HP.IV: is represented by CG423535/03/P[8]G1, CG513102/03/P[8]G1, CG520839/03/P[8]G1, CG795087/03/P[8]G1, CG816414/03/P[8]G1, CG817198/03/P[8]G1 and CG827082/03/P[8]G1 samples; HP.V: is represented by CG518035/03/P[8] G1 and CG842284/03/P[8]G1 samples; HP.VI: is represented by CG785797/03/P[8G1], CG789219/03/P[8]G1, CG794537/03/P[8]G1 and CG837155/03/P[8]G1 samples; HP.VII: is represented by CG819946/03/P[8]G3, CG826796/03/P[8]G9 and CG857722/03/P[8]G1 samples.

\section{TABLE III}

Combinations of NSP4 and G and P genotypes of group A rotaviruses samples obtained from children at West Central region of Brazil considering the years of sample collection

\begin{tabular}{lccc}
\hline Genotypes & \\
G and P & NSP4 genotypes & 1990-1999 & 2000-2003 \\
\cline { 2 - 4 } P[6]G9 & A & n & n \\
P[8]G1 & B & 13 & - \\
P[6]G1 & $\mathrm{B}$ & 1 & 35 \\
P[8]G2 & B & 1 & 1 \\
P[8]G3 & B & - & - \\
P[8]G4 & B & - & 3 \\
P[8]G9 & B & - & 4 \\
\hline
\end{tabular}

$a$ : see Cardoso et al. (2003), Souza et al. (2003), Costa et al. (2004), Andreasi et al. (2007). sequences of symptomatic and asymptomatic samples. These results are consistent with other investigations (Horie et al. 1997, Lee et al. 2000, Mascarenhas et al. 2007); however, since only two samples from children without diarrhea were analyzed, the role of NSP4 as a possible pathogenic determinant of rotavirus could not be assessed in this work.

Surveys around the world indicate that P[8]G1, P[4] $\mathrm{G} 2, \mathrm{P}[8] \mathrm{G} 3$ and $\mathrm{P}[8] \mathrm{G} 4$ are the most common $\mathrm{G}$ and $\mathrm{P}$ genotypes combinations isolated in children with diarrhea caused by group A rotavirus. More recent studies have shown the emergence of P[8]G9 and P[6]G9 genotypes in cases of severe diarrhea in children (Santos \& Hoshino 2005, Estes \& Kapikian 2007, Munford et al. 2007, Matthijnssens et al. 2008). In this study, rotavirus samples representing the $\mathrm{P}[8] \mathrm{G} 1, \mathrm{P}[6] \mathrm{G} 1, \mathrm{P}[8] \mathrm{G} 2, \mathrm{P}[8]$ 

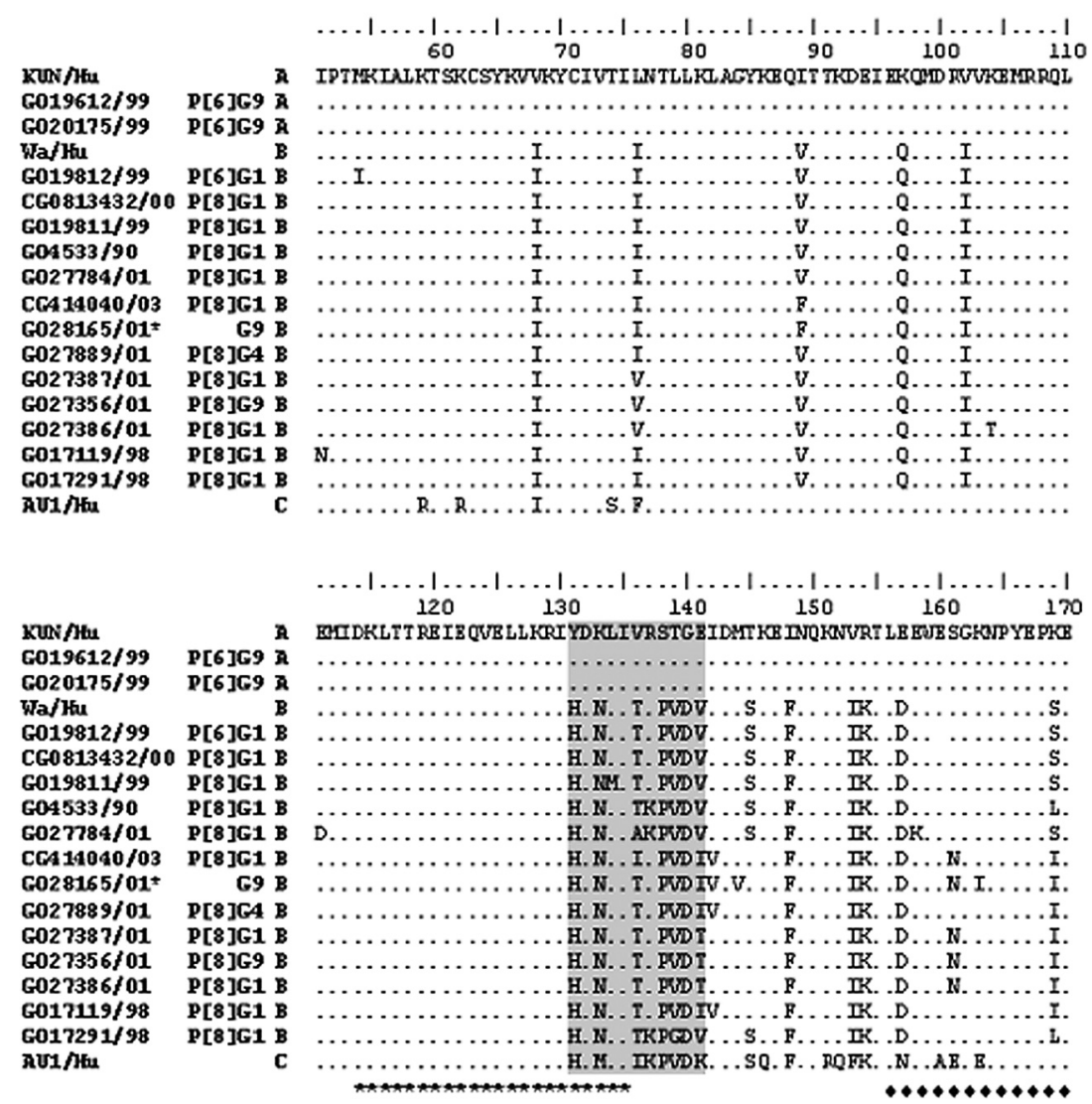

Fig. 2: multiple alignment of the partial deduced amino acid sequence of the NSP4 protein of 15 human rotaviruses samples with human prototype strains grouped in genotypes A, B and C. Dots indicate identity to the KUN/Hu strain. Gray box indicates interspecies variable domain. Diamonds indicate VP6 binding site. Asterisks indicate enterotoxigenic domain, assymptomatic child.

G3, P[8]G4 and P[8]G9 genotypes were more closely related to NSP4 genotype B comprising human reference strains Wa and AU32 (bootstrap value of $100 \%$ ), whereas $\mathrm{P}[6] \mathrm{G} 9$ rotavirus samples were closely related to NSP4 genotype $\mathrm{A}$, comprising human reference strains RV5 and KUN (bootstrap value of $100 \%$ ). In RJ, it was observed that $\mathrm{P}[8] \mathrm{G} 1, \mathrm{P}[8] \mathrm{G} 5$ and $\mathrm{P}[8] \mathrm{G} 9$ rotavirus strains from children were also more closely related to NSP4 genotype $\mathrm{B}$, while $\mathrm{P}[4] \mathrm{G} 2$ strains were associated with genotype A (Araújo et al. 2007). Mascarenhas et al. (2007) observed that, among children in nurseries in Belém, P[6]G9 samples were also associated with genotype A, while P[6]G4 strains were associated with genotype $\mathrm{B}$. In addition, $\mathrm{P}[6] \mathrm{G} 2$ rotavirus strains clustered with genotype $\mathrm{A}$ in previous investigations (Mascarenhas et al. 2006). Interestingly, some P[4]G2 and P[6] G9 rotavirus strains characterized as NSP4 genotype A, and P[8]G1, P[6]G1, P[8]G3, P[8]G4 and P[8]G9 strains characterized as genotype $\mathrm{B}$ recovered from children in studies from Brazil, including the present study, were also identified from patients in the United States (Kirkwood et al. 1999), Taiwan (Lee et al. 2000), the United Kingdom (UK) and India (Iturriza-Gómara et al. 2003).

Amino acid variations between genotypes $\mathrm{A}$ and $B$ were concentrated mainly in the interspecies variable domain (aa 131-141) and in the VP6 binding region (aa 156-175) (Estes \& Kapikian 2007). Our data on the region of aa 131-141 are similar to a study from Brazil (Araújo et al. 2007), considering the occurrence of extensive variation in this region, as well as to a study performed in the UK (Iturriza-Gómara et al. 2003). In addition, in the present study, it was observed that aa 131 was identified as tyrosine (genotype A) or histidine (genotype B), similar to the results of Mascarenhas et al. (2007), but contrary to the common postulate that diarrheic samples have a tyrosine at this position (Ball et al. 1996). Our results are also in agreement with other investigations (Cunlife et al. 1997, Iturriza-Gómara et al. 2003, Araújo et al. 2007), and they suggest that at these NSP4 protein regions are distinct between genotypes.

The immune response to A and B genotypes of the NSP4 gene has not yet been defined, and it is still unknown whether the inclusion of this gene in rotavirus vaccination strategies is important (Araújo et al. 2007). In this context, the possible selection of NSP4 as a target for vaccine development requires further investigation (Lee et al. 2000, Araújo et al. 2007).

In this study, the nucleotide sequence of the NSP4 gene was determined for the first time in 153 human rotavirus strains belonging to genotypes of different $\mathrm{G}$ and $\mathrm{P}$ combinations recovered from children with or without diarrhea in West Central region of Brazil. The NSP4 gene 
analysis performed in our study provides insight into the genetic relationships between different rotaviruses samples circulating in a particular region of Brazil.

\section{REFERENCES}

Altschul SF, Gish W, Miller W, Myers EW, Lipman DJ 1990. Basic local alignment search tool. J Mol Biol 215: 403-410.

Andreasi MSA, Batista SMF, Tozetti IA, Ozaki CO, Nogueira MM, Fiaccadori FS, Borges AMT, Santos RAT, Cardoso DDP 2007. Rotavírus A em crianças de até três anos de idade, hospitalizadas com gastroenterite aguda em Campo Grande, Estado do Mato Grosso do Sul. Rev Soc Bras Med Trop 40: 411-414.

Araújo IT, Heinemann MB, Mascarenhas JDP, Assis RMS, Fialho AM, Leite JPG 2007. Molecular analysis of NSP4 and VP6 genes of rotavirus strains recovered from hospitalized children in Rio de Janeiro, Brazil. J Med Microbiol 56: 854-859.

Ball JM, Tian P, Zeng CQ, Morris AP, Estes MK 1996. Age-dependent diarrhea induced by a rotaviral nonstructural glycoprotein. Science 272: 101-104.

Boom R, Sol CJA, Salimans MMM, Jansen CL, Wertheim-van Dillen PME, van der Noordaa J 1990. Rapid and simple method for purification of nucleic acids. J Clin Microbiol 28: 495-503.

Cardoso DDP, Soares CMA, Azevedo MSP, Leite JPG, Munford V, Rácz ML 2002. Serotypes and subgroups of rotavirus isolated from children in Central Brazil. Med Sci Monit 8: 624-628.

Cardoso DDP, Soares CMA, Souza MBLD, Azevedo MSP, Martins RMB, Queiróz DAO, Brito WMED, Munford V, Rácz ML 2003. Epidemiological features of rotavirus infection in Goiânia, Goiás, Brazil, from 1986 to 2000. Mem Inst Oswaldo Cruz 98: 25-29.

Cauás RC, Falbo AR, Correia JB, Oliveira KMM, Montenegro FMU 2006. Diarréia por rotavírus em crianças desnutridas hospitalizadas no Instituto Materno Infantil Prof. Fernando Figueira, IMIP. Rev Bras Saude Matern Infant 6: 77-83.

Cho SL, Ahn JH, Kim K, Chung SI, Lim I, Kim W 2006. Genetic variation in the NSP4 gene of human rotavirus isolated in Seoul. J Bacteriol Virol 36: 79-87.

Ciarlet M, Liprandi F, Conner ME, Estes MK 2000. Species specificity and interspecies relatedness of NSP4 genetic groups by comparative NSP4 sequence analyses of animal rotaviruses. Arch Virol 145: 371-383.

Costa PSS, Cardoso DDP, Grisi SJFE, Silva PA, Fiaccadori F, Souza MBLD, Santos RAT 2004. Infecções e reinfecções por Rotavirus A: genotipagem e implicações vacinais. J Pediatr 80: 119-122.

Cunliffe NA, Woods PA, Leite JPG, Das BK, Ramachandran M, Bhan MK, Hart CA, Glass RI, Gentsch JR 1997. Sequence analysis of NSP4 gene of human rotavirus allows classification into two main genetic groups. J Med Virol 53: 41-50.

Estes MK, Kapikian AZ 2007. Rotaviruses. In DM Knipe, PM Howley, Fields Virology, Lippincott Williams \& Wilkins, Philadelphia, p. 1917-1974.

Ewing B, Green P 1998. Base-calling of automated sequencer traces using phred. II. Error probabilities. Genome Res 8: 186-194.

Gulati BR, Deepa R, Singh BK, Durga Rao C 2007. Diversity in Indian equine rotaviruses: identification of genotype G10,P6[1] and G1 strains and a new VP7 genotype (G16) strain in specimens from diarrheic foals in India. J Clin Microbiol 45: 972-978.

Horie Y, Masamune O, Nakagomi O 1997. Three major alleles of rotavirus NSP4 proteins identified by sequence analysis. J Gen Virol 78: $2341-2346$.
Iturriza-Gómara M, Anderton E, Kang G, Gallimore C, Phillips W, Desselberger U, Gray J 2003. Evidence for genetic linkage between the gene segments encoding NSP4 and VP6 proteins in common and reassortant human rotavirus strains. J Clin Microbiol 41: 3566-3573.

Kirkwood CD, Gentsch JR, Glass RI 1999. Sequence analysis of the NSP4 gene from human rotavirus strains isolated in the United States. Virus Genes 19: 113-122.

Lee CN, Wang YL, Kao CL, Zao CL, Lee CY, Chen HN 2000. NSP4 gene analysis of rotaviruses recovered from infected children with and without diarrhea. J Clin Microbiol 38: 4471-4477.

Lin SL, Tian P 2003. Detailed computational analysis of a comprehensive set of group A rotavirus NSP4 proteins. Virus Genes 26: 271-282.

Linhares AC 2000. Epidemiologia das infecções por rotavírus no Brasil e os desafios para o seu controle. Cad Saude Publica 16: 629-646.

Martella V, Ciarlet M, Bányai K, Lorusso E, Arista S, Lavazza A, Pezzotti G, Decaro N, Cavalli A, Lucente MS, Corrente M, Elia G, Camero M, Tempesta M, Buonavoglia C 2007. Identification of group A porcine rotavirus strains bearing a novel VP4 (P) genotype in Italian swine herds. J Clin Microbiol 45: 577-580.

Mascarenhas JDP, Linhares AC, Bayma APG, Lima JC, Sousa MS, Araújo IT, Heinemann MB, Gusmão RHP, Gabbay YB, Leite JPG 2006. Molecular analysis of VP4, VP7, and NSP4 genes of P[6]G2 rotavirus genotype strains recovered from neonates admitted to hospital in Belém, Brazil. J Med Virol 78: 281-289.

Mascarenhas JDP, Linhares AC, Gabbay YB, Lima CS, Guerra SFS, Soares LS, Oliveira DS, Lima JC, Mâcedo O, Leite JPG 2007. Molecular characterization of VP4 and NSP4 genes from rotavirus strains infecting neonates and young children in Belém, Brazil. Virus Res 126: 149-158.

Matthijnssens J, Ciarlet M, Heiman E, Arijs I, Delbeke T, McDonald SM, Palombo EA, Iturriza-Gómara M, Maes P, Patton JT, Rahman M, Van Ranst M 2008. Full genome-based classification of rotaviruses reveals a common origin between human Wa-Like and porcine rotavirus strains and human DS-1-like and bovine rotavirus strains. J Virol 82: 3204-3219.

Mori Y, Borgan MA, Ito N, Sugiyama M, Minamoto N 2002. Sequential analysis of nonstructural protein NSP4s derived from group A avian rotaviruses. Virus Res 89: 145-151.

Munford V, Souza EC, Caruzo TAR, Martinez MB, Rácz ML 2007. Serological and molecular diversity of human rotavirus in São Paulo, Brazil. Braz J Microbiol 38: 459-466.

Parashar UD, Gibson CJ, Bresee JS, Glass RI 2006. Rotavirus and severe childhood diarrhea. Emerg Infect Dis 12: 304-306.

Pereira HG, Azeredo RS, Leite JPG, Andrade ZP, Castro L 1985. A combined enzyme immunoassay for rotavirus and adenovirus (EIARA). J Virol Methods 10: 21-28.

Pereira HG, Azeredo RS, Leite JPG, Candeias JAN, Rácz ML, Linhares AC, Gabbay YB, Trabulsi JR 1983. Electrophoretic study of the genome of human rotaviruses from Rio de Janeiro, São Paulo and Pará, Brazil. Am J Hyg 90: 117-125.

Saitou N, Nei M 1987. The neighbor-joining method: a new method for reconstructing phylogenetic trees. Mol Biol Evol 4: 406-425.

Santos N, Hoshino Y 2005. Global distribution of rotavirus serotypes/ genotypes and its implication for the development and implementation of an effective rotavirus vaccine. Rev Med Virol 15: 29-56.

Souza MBLD, Rácz ML, Leite JPG, Soares CMA, Martins RMB, Munford V, Cardoso DDP 2003. Molecular and serological characterization of group A rotavirus isolates obtained from hospital- 
ized children in Goiânia, Brazil, 1998-2000. Eur J Clin Microbiol Infec Dis 22: 441-443.

Taylor JA, Bellamy AR 2003. Interaction of the rotavirus nonstructural giycoprotein NSP4 with the viral and cellular components. In U Desselberger, J Gray, Viral Gastroenteritis, Elsevier Science, Amsterdam, p. 225-235.

Thompson JD, Gibson TJ, Plewniak F, Jeanmougin F, Higgins DG 1997. The Clustal X windows interface: flexible strategies for multiple sequence alignment aided by quantity analysis tools. Nucleic Acids Res 25: 4876-4882.

Vizzi E, Calviño E, González R, Pérez-Schael I, Ciarlet M, Kang G,
Estes MK, Liprandi F, Ludert JE 2005. Evaluation of serum antibody responses against the rotavirus nonstructural protein NSP4 in children after Rhesus rotavirus tetravalent vaccination or natural infection. Clin Diagn Lab Immunol 12: 1157-1163.

Yuan L, Ishida S, Honma S, Patton JT, Hodgins DC, Kapikian AZ, Hoshino Y 2004. Homotypic and heterotypic serum isotypespecific antibody responses to rotavirus nonstructural protein 4 and viral protein (VP) 4, VP6, and VP7 in infants who received selected live oral rotavirus vaccines. J Infect Dis 189: 1833-1845.

Zhang M, Zeng CQY, Dong Y, Ball JM, Saif LJ, Morris AP, Estes MK 1998. Mutations in rotavirus nonstructural glycoprotein NSP4 are associated with altered virus virulence. $J$ Virol 72: 3666-3672. 